\title{
HASIL TANGKAPAN JUVENIL UDANG DI PERAIRAN SUNGAI DAN MUARA WULAN, DEMAK DENGAN MENGGUNAKAN ALAT PERANGKAP
}

\author{
Shrimp Juvenile in Wulan River and Estuarine, Demak Application of a Trap Equipment
}

\section{Amalia Nur Istigfarin, Boedi Hendrarto*), Anhar Solichin}

Program Studi Manajemen Sumberdaya Perairan, Jurusan Perikanan

Fakultas Perikanan dan Ilmu Kelautan, Universitas Diponegoro

Jl. Prof. Soedarto, SH, Tembalang, Semarang, Jawa Tengah - 50275, Telp/Fax. +6224 7474698

Email : amalianuris@gmail.com

\begin{abstract}
ABSTRAK
Perairan Sungai dan Muara Wulan, Demak merupakan wilayah perairan yang memiliki keanekaragaman spesies, contohnya udang. Wilayah perairan Sungai Wulan dimanfaatkan para nelayan untuk menangkap ikan, udang, kerang dan biota lainnya. Alat perangkap digunakan untuk mengetahui kondisi populasi juvenil udang yang terdapat di dasar perairan Sungai dan Muara Wulan. Tujuan dari penelitian ini yaitu mengetahui jenis juvenil yang tertangkap, mengetahui adanya pengaruh lokasi penelitian, dan mengetahui pola pertumbuhan juvenil. Metode penelitian yang digunakan adalah metode deskriptif. Penelitian dilakukan pada tanggal 7 Mei - 4 Juni 2016.Pengambilansampeljuveniludangdilakukanpadaduastasiun yaitusungaidanmuara yang terdiridaritigatitikdalamperiode I sampaiperiode IV. Hasil tangkapan pada perangkap di simpan dalam botol sampel dan direndam dalam formalin 5\%.Hasil yang diperolehdidapatkanjenisjuveniludangdari genus MetapenaeusdanPenaeus. Jumlahseluruhjuveniludang didapatkan di perairansungailebihsedikitdibandingkanperairanmuara. Jumlahjuveniludang genus Metapenaeus yang terperangkappadaalatlebih banyak dari genus Penaeus. Jumlah seluruh juvenil udang yang didapatkan sebanyak 103 individu. Polapertumbuhan kedua jenisjuveniludangadalahbersifat allometriknegatif.
\end{abstract}

Kata Kunci : Juvenil Udang, Muara Sungai Wulan Demak, Pola Pertumbuhan.

\section{ABSTRACT}

Wulan River and Estuarine in Demak have a diversity of species, such as shrimp. Wulan river exploited by fishermen to catch fish, shrimp, shellfish and others. To find out the condition of the juvenile shrimp's population in the Wulan river and estuary, has been studied by using a trap. The study aims to find out the type of juvenile shrimps that were trapped, the growth pattern, and the effect of the location.Juvenile shrimps sampling was performed in two stations, one on the river and one other on the estuary which consist of three points in period I until period IV. Catches resulted in the trap was stored in sample bottles and was soaked in 5\% formalin. It was obtained that the juvenile shrimps type collected was from MetapenaeusdanPenaeus genus. Total numbers of juvenile shrimps obtained in the river was less than in the estuary.The numbers of Metapenaeus genus trapped was more than Penaeus genus. The overall numbers of juvenile shrimps caught was 103 juveniles. The growth pattern ofjuvenile shrimps was negatively allometric.

Keywords: Shrimps juvenile, Wulan River and Estuarine Demak, Growth Pattern.

\section{PENDAHULUAN}

Udang merupakan salah satu biota yang terdapat pada beberapa ekosistem dan merupakan komoditas yang digemari masyarakat dan menjadi salah satu komoditas penting di sektor perikanan Indonesia.Alat penangkapan udang terus dikembangkan setiap tahunnya untuk membantu nelayan memperoleh udang dengan jumlah yang banyak namun, semakin dikembangkan alat semakin alat itu berpotensi terhadap kerusakan ekosistem. Hilangnya suatu spesies yang disebabkan oleh pencemaran perairan atau eksploitasi berlebihan sehingga kelimpahan suatu spesies tergantung oleh keadaan biotik dan abiotik ekosistem. Menurut Saputra (2015), pembentukan stok udang penaeid terutama dipengaruhi oleh faktor-faktor alamiah dan faktor manusia. Faktor-faktor alamiah terutama adalah kesesuaian habitat, yang akan menentukan kemampuan udang untuk dapat tumbuh, bereproduksi, memijah dan akhirnya rekrut ke dalam stok.

Perairan Sungai dan Muara Wulan merupakan wilayah perairan yang memiliki keanekaragaman spesies, contohnya udang. Wilayah perairan Sungai Wulan dimanfaatkan para nelayan untuk menangkap ikan, udang, kerang dan biota lainnya. Kegiatan penangkapan yang berlebihan dan tidak selektif dapat membahayakan

${ }^{\circ}$ Copyright by Management of Aquatic Resources (MAQUARES) 
siklus hidup biota yang berada pada wilayah perairan tersebut dan juga berpengaruh terhadap kesuburan perairan. Kesuburan perairan dipengaruhi oleh faktor kimia, fisika dan kelimpahan biota termasuk kelimpahan juvenil udang. Jumlah juvenil udang yang didapatkan di perairan Wulan dipengaruhi oleh parameter perairan seperti kedalaman, kecerahan, suhu, arus, ph dan salinitas. Stasiun serta titik sampling juga dapat mempengaruhi jenis dan jumlah juvenil yang tertangkap.

Tujuan dilakukannya penelitian ini adalah (1) mengetahui jenis dan jumlah juvenil udang yang tertangkap dengan alat perangkap di Sungai dan Muara Wulan, Demak; (2) mengetahui pengaruh lokasi (Sungai dan Muara Wulan) terhadap kelimpahan juvenil; dan (3) mengetahui pola pertumbuhan juvenil yang tertangkap pada alat perangkap

\section{MATERI DAN METODE PENELITIAN}

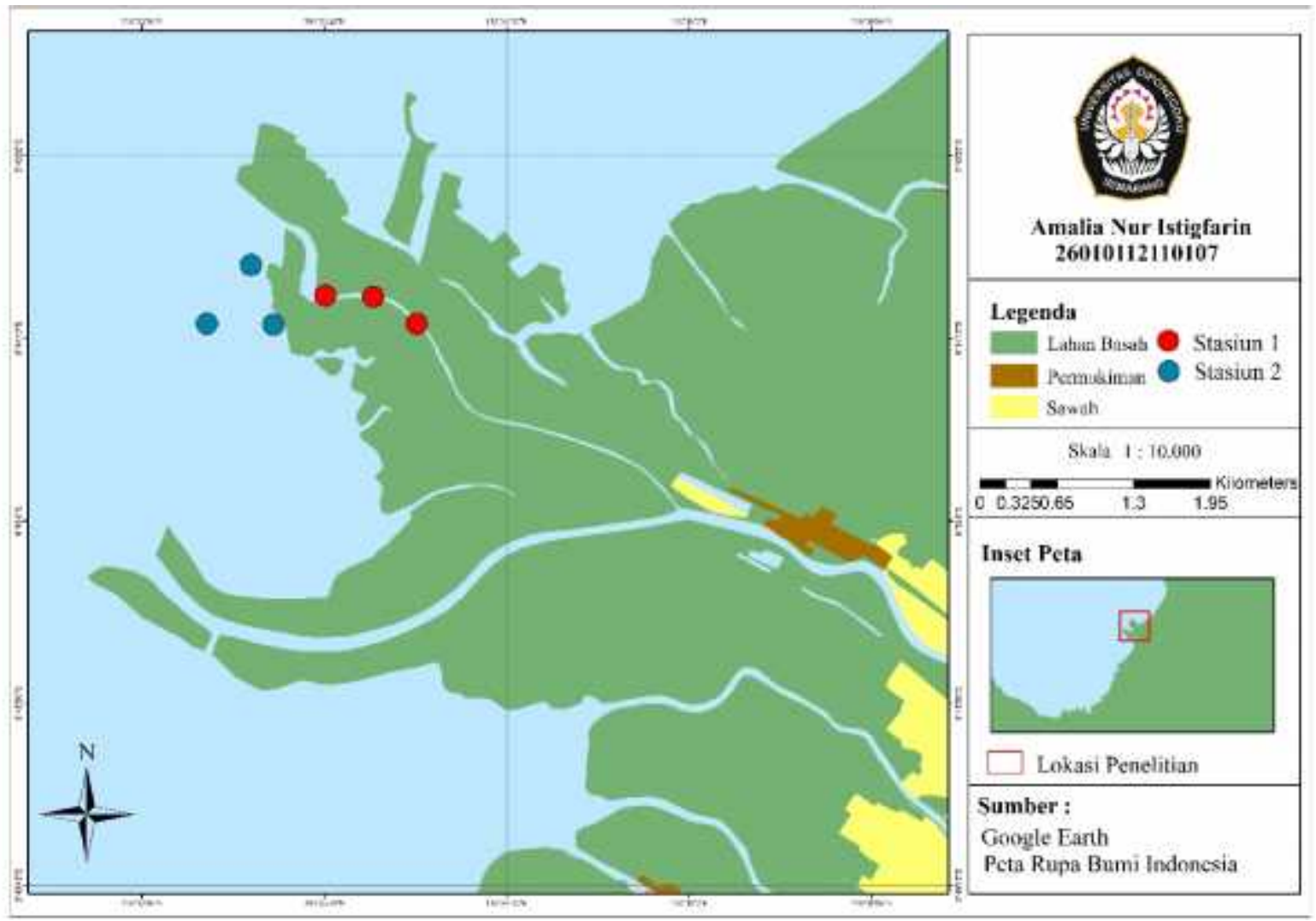

Gambar 1. Peta lokasi penelitian

Lokasi penelitian berada di Sungai dan Muara Wulan yang terletak di Desa Menco Kecamatan Wedung, Kabupaten Demak. Desa Menco termasuk dalam wilayah yang merupakan daerah pesisir pantai yang dilalui sungai Wulan dan Muara Wulan yang terdapat mangrove. Sampling lapangan dilakukan di 2 stasiun. Stasiun 2 berada di Sungai Wulan, stasiun 2 berada di Muara Wulan (Gambar 1). Pengambilan sampel juvenil menggunakan alat perangkap. Juvenil ditangkap dengan merendam alat berupa tabung yang terbuat dari besi dan bambu dengan diameter $40 \mathrm{~cm}$ dan dilapisi jaring yang memiliki mesh size $1 \mathrm{~mm}$. Tali diikatkan pada bagian atas alat dan dipasangkan pelampung atau botol plastik kosong sebagai penanda keberadaan alat di perairan. Alat perangkap yang digunakan berjumlah 3 buah untuk diletakkan pada titik sampling pada saat yang bersamaan. Perendaman dilakukan selama 3 jam selama waktu surut. Perangkap yang telah direndam selama 3 jam kemudian diangkat dan diamati banyaknya juvenil yang menempel pada trap tersebut. Hasil tangkapan pada perangkap di simpan dalam botol sampel dan direndam dalam formalin $5 \%$.

\section{Identifikasi juvenil udang}

Pengidentifikasian juvenil udang dibantu dengan menggunakan buku identifikasi Saputra (2008) dan FAO Species Catalogue : Vol. 1 - Shrimps and Prawns Of The World (1980).

\section{Pengukuran parameter fisika dan kimia perairan}

Pengukuran parameter kimia dan fisika perairan dilakukan pada setiap titik pengambilan sampel. Pengukuran meliputi suhu menggunakan termometer, kecerahan dan kedalaman menggunakan secchi disk, $\mathrm{pH}$ menggunakan $\mathrm{pH}$ paper, GPS untuk mengetahui titik koordinat lokasi, salinitas menggunakan refraktometer, dan arus menggunakan bola arus.

\section{Analisis data}


a. Analisa Statistik dengan Nested (Hierarchical) Analysis of Variance

Perhitungan dengan Nested (Hierarchical) Analysis of Variance untuk mengetahui kemungkinan terdapat pengaruh lokasi terhadap hasil tangkapan. Hipotesis dalam penelitian ini adalah sebagai berikut:

$\mathrm{H}_{0}$ : tidak ada perbedaan hasil tangkapan dari ketiga titik pengamatan

$\mathrm{H}_{1}$ : terdapat perbedaan hasil tangkapan dari ketiga titik pengamatan

Perhitungan $\mathrm{F}$ hitung didapatkan dari $\mathrm{F}=\frac{\text { subgroup Ns }}{\text { eTror } \mathrm{N2}}$, apabila $\mathrm{F}$ hitung $<\mathrm{F}$ tabel maka $\mathrm{H}_{0}$ terima. Selanjutnya untuk melihat apakah terdapat perbedaan variabel yang disebabkan oleh grup, terdapat dua hipotesis:

$\mathrm{H}_{0}$ : tidak ada perbedaan jumlah juvenil udang yang diperoleh dari dua lokasi berbeda (sungai dan muara)

$\mathrm{H}_{1}$ : terdapat perbedaan dalam jumlah juvenil udang yang diperoleh dari dua lokasi berbeda (sungai dan muara)

Perhitungan $\mathrm{F}$ hitung didapatkan dari $\mathrm{F}=\frac{\text { Group NS }}{\text { suggroup } N \text { s }}$, apabila $\mathrm{F}$ hitung $<\mathrm{F}$ tabel maka $\mathrm{H}_{0}$ terima.

\section{b. Hubungan Panjang Berat}

Hubungan panjang dan berat dalam penelitian ini dimaksudkan untuk mengetahui bentuk pertumbuhan juvenil udang yang tertangkap dengan menggunakan metode perangkap agar-agar dalam periode yang berbeda yaitu periode satu sampai periode empat. Menurut Effendie (2002), analisis panjang dan berat bertujuan untuk mengetahui sifat pertumbuhan dari spesies yang diukur dengan menggunakan persamaan sebagai berikut:

$$
\mathrm{W}=\mathrm{aLb}
$$

Keterangan:

$\mathrm{W}=$ berat tubuh $($ gram $)$

$\mathrm{L}=$ panjang karapas $(\mathrm{mm})$

$\mathrm{a}=$ Intercept

$\mathrm{b}=$ Slope

Persamaan ini dapat diselesaikan melalui transformasi linear logaritme dalam bentuk sebagai berikut : $\log \mathrm{W}=\log \mathrm{a}+\mathrm{b} \log \mathrm{L}$

Dengan demikian persamaan ini dapat diselesaikan seperti menyelesaikan persamaan linier biasa. Uji t nilai $b$ terhadap 3 bertujuan untuk mengetahui apakah pertumbuhan tergolong isometrik atau alometrik. Dengan hipotesis sebagai berikut:

H0 : Nilai $b=3$, sehingga pertumbuhan bersifat isometrik

$\mathrm{H} 1$ : Nilai $\mathrm{b} \neq 3$, sehingga pertumbuhan bersifat allometrik

Jika $\mathrm{b}=3$, maka pertumbuhannya isometrik, yaitu tingkat pertumbuhan panjang, lebar dan tinggi ikan adalah sama. Jika tidak sama dengan 3, pertumbuhannya allometrik, yaitu allometrik positif apabila $b>3$ dan allometrik negatif apabila $\mathrm{b}<3$.

\section{HASIL DAN PEMBAHASAN}

Hasil

\section{a. Juvenil Udang}

Juvenil udang yang didapatkan dari perairan Sungai dan Muara Wulan terdiri dari genus Metapenaeus dan genus Penaeus. Perbedaan utama dalam morfologi kedua genera juvenil udang ini adalah dari bentuk rostrum. Udang Metapenaeus memiliki rostrum yang terdapat gerigi pada bagian atasnya, sedangkan udang Penaeus terdapat gerigi pada bagian atas dan bawah rostrumnya. Tubuh kedua genera udang ini memiliki ciri yang serupa yaitu berwarna putih dan terdapat bintik bintik hitam ditubuhnya, namun untuk Penaeus tubuh bersih dari groove.

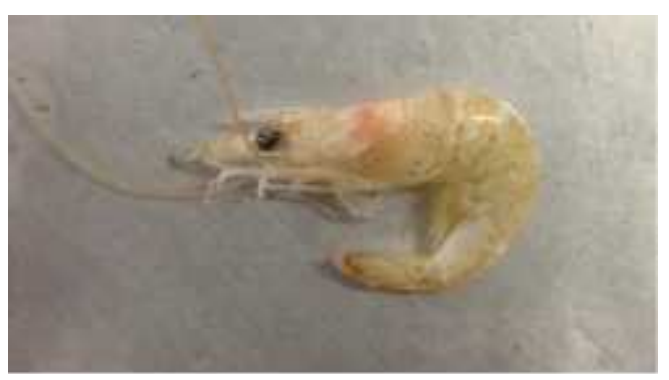

Gambar 2. Juvenil Udang Penaeus

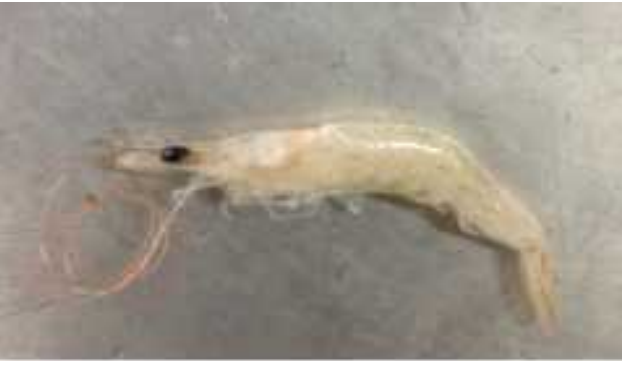

Gambar 3. Juvenil Udang Metapenaeus

Jumlah juvenil yang didapatkan di sungai sebanyak 14 ekor dan di muara sebanyak 89 ekor. Jumlah seluruh juvenil udang yang didapatkan dari perairan sungai dan muara sebanyak 103 ekor. Juvenil udang yang tertangkap dengan alat perangkap yaitu juvenil udang Metapenaeus dan Penaeus. Jumlah juvenil udang yang didapatkan pada alat perangkap di perairan Sungai dan Muara Wulan per periode selama penelitian tersaji dalam Tabel 1.

\footnotetext{
${ }^{\text {CC }}$ Copyright by Management of Aquatic Resources (MAQUARES)
} 
Tabel 1. Juvenil Udang yang Tertangkap di Perairan Sungai dan Muara Wulan PerPeriode

\begin{tabular}{lccccccccc}
\hline \multirow{2}{*}{ Stasiun } & \multicolumn{3}{c}{ Metapenaeus } & \multicolumn{3}{c}{ Penaeus } & \multirow{2}{*}{ Total } \\
\cline { 2 - 9 } & I & II & III & IV & I & II & III & IV & \\
\hline Sungai & - & - & 3 & 2 & 3 & 1 & - & 5 & 14 \\
\hline Muara & 14 & 8 & 20 & 7 & 13 & 9 & 8 & 10 & 89 \\
\hline \multicolumn{1}{c}{ Jumlah } & & & & & 103 \\
\hline
\end{tabular}

Kelimpahan juvenil udang Metapenaeus lebih banyak didapatkan di muara dibandingkan dengan sungai, demikianpun untuk juvenil Penaeus lebih banyak didapatkan di muara. Grafik hasil tangkapan juvenil udang pada perairan sungai yang diperoleh selama periode I sampai periode IV tersaji pada Gambar 4.

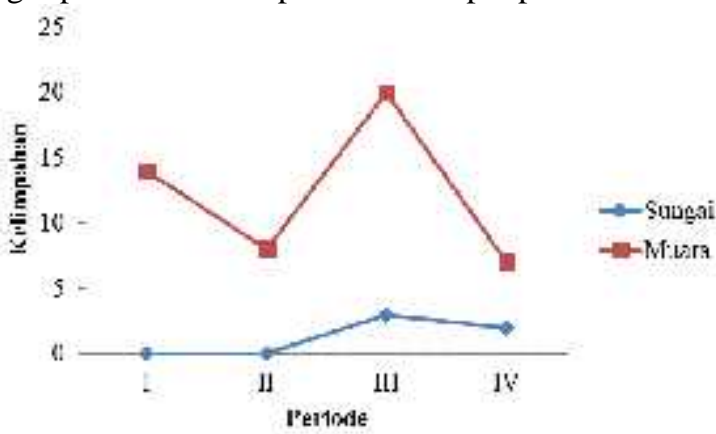

Gambar 4. Grafik Hasil Tangkapan Juvenil Udang Metapenaeus di Perairan Sungai dan Muara Wulan Per Periode

Gambar 4 menjelaskan hasil tangkapan juvenil udang Metapenaeus setiap periode selama penelitian pada perairan sungai dan muara. Hasil tangkapan yang didapatkan pada perairan muara lebih banyak dibandingkan dengan perairan sungai. Pada perairan muara jumlah tangkapan juvenil terbanyak terjadi pada periode ketiga, meningkat drastis dari periode kedua. Sedangkan pada perairan muara jumlah tangkapan terbanyak juga terjadi pada periode ketiga, setelah sebelumnya tidak didapatkan juvenil pada periode pertama dan kedua.Grafik hasil tangkapan juvenil udang Penaeus yang diperoleh selama penelitian periode I sampai periode IV pada perairan Sungai dan Muara Wulan tersaji pada Gambar 5.

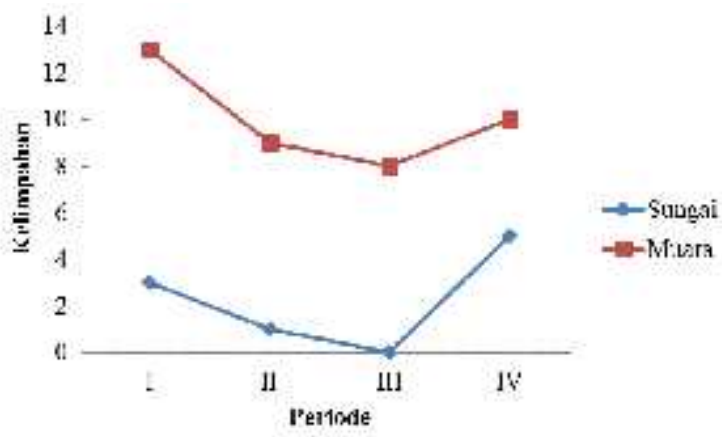

Gambar 5. Grafik Hasil Tangkapan Juvenil Udang Penaeus di Perairan Sungai dan Muara Wulan Per Periode

Gambar 3 menjelaskan hasil tangkapan juvenil udang Penaeus setiap periode selama penelitian pada perairan sungai dan muara. Hasil tangkapan yang didapatkan pada perairan muara lebih banyak dibandingkan perairan sungai, sama seperti hasil tangkapan udang Metapenaeus. Pada periode II pada perairan muara dan sungai udang hasil tangkapan menurun sampai periode III, hasil tangkapan meningkat kembali pada periode IV.

Taraf kepercayaan yang digunakan pada analisa nested ini yaitu 95\%, akan terlihat apakah terdapat pengaruh atau tidak.Untuk juvenil Metapenaeus nilai Fhitung yaitu $F=\frac{0,44}{0,24}=\mathbf{1}, \mathbf{8 3}\left(<\mathrm{F}_{0.05,4,8}=2,93\right)$, berarti tidak ada perbedaan antar titik sampling dalam pengaruh terhadap jumlah juvenil udang Metapenaeus yang diperoleh. Akan tetapi, jumlah juvenil Metapenaeus di kedua stasiun berbeda nyata yaitu $F=\frac{7,06}{0,44}=\mathbf{1 6 , 0 4}>$ $\mathrm{F}_{0.05,1,4}=7,71$ 
Untuk juvenil Penaeus nilai Fhitung yaitu $F=\frac{0, Z I}{0, \mathbf{I}}=\mathbf{1}, \mathbf{8}\left(<\mathrm{F}_{0.05,4,8}=2,93\right)$ berarti tidak ada perbedaan antartitik sampling dalam pengaruh terhadap jumlah juvenil udang Penaeus yang diperoleh.Jumlah juvenil Penaeus di kedua status berbeda yaitu $F=\frac{4,45}{U, Z I}=\mathbf{1 6}, \mathbf{4 8}>\mathrm{F}_{0.05,1,4}=7,71$.

Dalam penelitian ini juga dilakukan pengukuran terhadap faktor faktor lingkungan perairan seperti kedalaman, kecerahan, suhu, arus, $\mathrm{pH}$ dan salinitas. Nilai arus di sungai dan muara pada 3 titik selama 4 periode yaitu $0,02 \mathrm{~m} / \mathrm{s}$ dan $0,025 \mathrm{~m} / \mathrm{s}$. Nilai $\mathrm{pH}$ di sungai dan muara pada 3 titik selama 4 periode yaitu 8 . Nilai salinitas di sungai dan muara pada 3 titik selama 4 periode yaitu 5 ppt dan 25 ppt. Hasil pengukuran parameter perairan lainnya tersaji pada Tabel 2.

Tabel 2. Hasil Pengukuran Parameter Perairan Sungai dan Muara Wulan, Demak

\begin{tabular}{lcccccc}
\hline \multicolumn{1}{c}{ Parameter } & \multicolumn{3}{c}{ Sungai } & \multicolumn{3}{c}{ Muara } \\
\cline { 2 - 7 } & $\mathbf{1}$ & $\mathbf{2}$ & $\mathbf{3}$ & $\mathbf{4}$ & $\mathbf{5}$ & $\mathbf{6}$ \\
\hline Kedalaman $(\mathrm{cm})$ & 60 & 58 & 61 & 64 & 65 & 67 \\
Kecerahan $(\mathrm{cm})$ & 15 & 17 & 19 & 20 & 21 & 24 \\
Suhu Air $\left({ }^{\circ} \mathrm{c}\right)$ & 29 & 28 & 28 & 29 & 29 & 29 \\
Suhu Udara $\left({ }^{\circ} \mathrm{c}\right)$ & 30 & 30 & 30 & 30 & 30 & 30 \\
\hline
\end{tabular}

\section{b. Hubungan Panjang Berat}

Analisa hubungan panjang dan berat bertujuan untuk mengetahui sifat pertumbuhan juvenil. Hubungan panjang dan berat juvenil udang Metapenaeus selama penelitian tersaji pada Gambar 4.

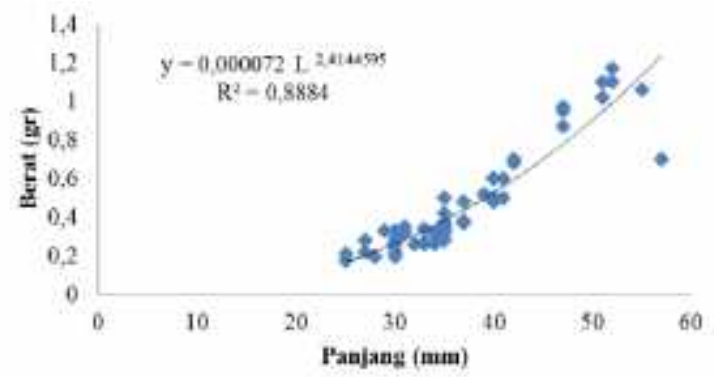

Gambar 4. Grafik Hubungan Panjang dan Berat Juvenil Metapenaeus

Nilai b untuk juvenil udang Metapenaeus yaitu 2,414. Hasil uji t menunjukan bahwa nilai $\mathrm{P}<0,01$. Hal ini berarti sifat pertumbuhan dari juvenil udang Metapenaeus allometrik. Karena $\mathrm{b}<3$ maka pertumbuhan bersifat allometrik negatif yaitu pertumbuhan panjang juvenil udang Metapenaeus lebih cepat daripada pertumbuhan beratnya.

Hubungan panjang tubuh dan berat tubuh juvenil udang Penaeus selama penelitian tersaji pada Gambar 5.

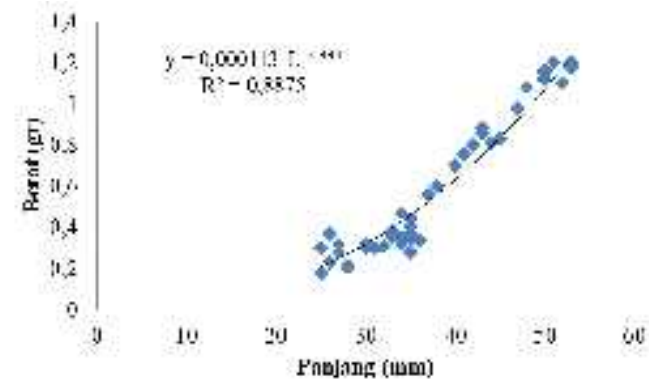

Gambar 5. Grafik Panjang dan Berat Juvenil Udang Penaeus

Berdasarkan hasil analisis regresi antara panjang tubuh $(\mathrm{mm})$ dan berat tubuh (gram) juvenil udang Penaeus didapatkan persamaan linier sebagai berikut $\mathrm{W}=\mathrm{W}=0,000113 \mathrm{~L}^{2,339}$. Nilai $\mathrm{b}$ untuk juvenil udang Penaeus yaitu 2,339. Hasil uji t menunjukan bahwa nilai $\mathrm{P}<0,01$. Hal ini berarti sifat pertumbuhan dari juvenil udang Penaeusyaitu allometrik. Karena $\mathrm{b}<3$ maka pertumbuhan bersifat allometrik negatif yaitu pertumbuhan panjang juvenil udang Penaeus lebih cepat daripada pertumbuhan beratnya. 


\section{Pembahasan}

a. Identifikasi dan hasil tangkapan juvenil udang

Berdasarkan hasil yang didapatkan dari penelitian yang dilakukan selama 4 minggu pada bulan Mei Juni 2016 di Desa Menco Kecamatan Wedung Kabupaten Demak, dengan menggunakan alat perangkap didapatkan juvenil udang, ikan, serta rajungan. Jenis juvenil udang yang tertangkap dari genus Metapenaeus dan Penaeus yang berasal dari famili Penaeidae, sedangkan untuk ikan dan rajungan tidak dilakukan identifikasi. Genus Metapenaeus tertangkap sebanyak 54 ekor dan genus Penaeus sebanyak 49 ekor. Bedasarkan ukuran dan hasil identifikasi, metapenaeus dan penaeus merupakan genus dari famili Penaeidae. Hal ini diperkuat oleh Holthuis (1980), Metapenaeus dan Penaeus termasuk ke dalam golongan udang caridea dan termasuk ke dalam famili Penaeidae.

Hasil identifikasi juvenil udang Metapenaeus dan Penaeus menunjukan bahwa juvenil udang memiliki morfologi yang hampir sama. Anggota tubuh terdiri dari 6 ruas dan memiliki telson yang berbentuk runcing segitiga. Pada bagian tubuh berwarna putih dan terdapat bintik bintik hitam kecil. Genus ini memiliki rostrum yang cukup panjang namun tidak melengkung. Hanya perbedaannya pada genus penaeus gigi gigi rostrum terdapat pada bagian atas dan bawah rostrum. Menurut Mudjiman (1994), juvenil Penaeid memiliki rostrum relatif kecil dan berbentuk seperti S (sigmoid) yang kuat dan panjang. Akan tetapi setelah dewasa rostrum menjadi lurus dan pendek. Sedangkan Menurut Pratiwi (2008), secara morfologi udang dari suku Penaeidae memiliki bentuk tubuh yang sama, yang terdiri dari 2 bagian yaitu bagian depan dan bagian belakang. Bagian depan disebut bagian kepala, yang terdiri dari bagian kepala dan dada (cephalothorax). Bagian belakang, terdiri dari perut (abdomen) dan ekor (telson). Seluruh anggota badan terdiri dari ruas-ruas (segmen) dari kepala 5 ruas dan dada 8 ruas, serta bagian perut 6 ruas. Keseluruhan tubuhnya ditutupi oleh kerangka luar yang disebut dengan eksoskleton dan terbuat dari kitin. Kerangka tersebut mengeras, kecuali pada sambungan sambungan antar dua ruas.

Berdasarkan hasil tangkapan juvenil udang yang didapatkan setiap periode, hasilnya berbeda-beda. Pengaruh lokasi, pakan, pengaruh periode serta faktor alam mempengaruhi jumlah juvenil yang didapatkan. Pada perairan Muara tertangkap udang sebanyak 89 ekor dan perairan Sungai tertangkap udang sebanyak 14 ekor. Diantara dua perairan penelitian yang digunakan yaitu perairan sungai dan perairan muara, jumlah hasil tangkapan juvenil udang lebih banyak didapatkan di perairan muara. Menurut Raymond (2011), udang Penaeid bertelur di laut, di mana telur tersebut dilepaskan bebas ke dalam perairan dan berkembang sendirinya, selama berkembang larva-larva berenang menuju pantai dan stadia juvenil sebagian hidupnya di daerah muara atau di dasar perairan yang memiliki substrat lunak seperti lumpur atau pasir.

Dari empat periode melakukan penelitian hasil tangkapan udang yang didapatkan sedikit. Hasil tangkapan hanya mencapai belasan ekor, namun paling tinggi pada periode ketiga yaitu 20 ekor. Bedasarkan data pasang surut BMKG periode ketiga memiliki ketinggian tertinggi yaitu $0,9 \mathrm{~m}$. Ketinggian pasang surut pada periode satu, dua dan empat tidak mencapai pasang tertinggi sehingga hal ini mempengaruhi hasil tangkapan. Menurut Arshad (2010) dalam Riyana (2015), besar kecilnya arus pasang surut serta kondisi lingkungan merupakan faktor utama yang dapat menyebabkan perubahan pada kelimpahan, distribusi serta spesies yang ada dalam suatu habitat. Proses pasang surut atau naik turunnya permukaan air laut dapat mempengaruhi aliran massa air laut yang didalamnya termasuk biota-biota planktonik terutama di muara sungai.

Hasil tangkapan dari stasiun muara dan sungai yang berbeda dapat dipengaruhi oleh lokasi pengambilan sampel. Stasiun Sungai ditumbuhi vegetasi pada pinggir sungai dan Muara ditumbuhi mangrove jenis Rhizophora sp dan Avicennia sp. Muara yang ditumbuhi mangrove memiliki tipe dasar perairan yang lembut berupa campuran lumpur dan pasir. Beberapa jenis udang bergantung terhadap habitat mangrove sebagai tempat berlindung, daerah asuhan, dan tempat mencari makan. Menurut Tjahjo dan Astri (2013), pada dasarnya udang penaeid senang tinggal di daerah dimana terjadi pecampuran air sungai dan air laut, karena di daerah ini banyak tersedia makanan dan unsur hara yang dibutuhkan udang, seperti daerah hutan bakau dimana di daerah tersebut disamping mampu menyediakan makanan secara kontinyu, dan dapat berperan sebagai tempat perlindungan bagi udang tersebut. Menurut Pratiwi (2008), menyatakan bahwa udang Penaeus, memiliki daya penyesuaian yang tinggi terhadap semua tipe dasar perairan, tetapi lebih menyukai dasar perairan lumpur liat berpasir.Menurut penelitian yang dilakukan oleh Macia (2004) di Pulau Inhaca Mozambiq, menunjukkan bahwa hutan mangrove yang berdekatan dengan lokasi penelitian sangatdimanfaatkan oleh udang pasca larva dan juvenile penaeidselama tahap awal dari siklus hidup mereka, karena genus Metapenaeus dan Penaeus memiliki ukuran yang cukup besar saat ditangkap pada daerah mangrove maupun yang berdekatan dengan mangrove.

Beberapa faktor lain yang mempengaruhi jumlah juvenil udang yang didapatkan salah satunya faktor alam seperti kedalaman, kecerahan, $\mathrm{pH}$, salinitas, dan arus. Hasil pengukuran kedalaman diperoleh kedalaman rata rata perairan sungai yaitu berkisar $60-61 \mathrm{~cm}$ dan rata rata perairan muara berkisar $64-67 \mathrm{~cm}$. Menurut Soekotjo (2002), kedalaman yang terlalu dangkal akan membuat suhu perairan menjadi tinggi dan dapat menyebabkan kematian larva dan juvenil karena stadia ini rawan akan perubahan suhu. Kedalaman perairan juga berpengaruh terhadap jumlah organisme yang mendiami perairan. Selain itu kedalaman juga berpengaruh terhadap penyebaran larva dan juvenil. Juvenil udang biasanya menyebar pada kedalaman 1 meter sampai 20 meter.

() Copyright by Management of Aquatic Resources (MAQUARES) 
Hasil pengukuran salinitas menggunakan refraktometer pada perairan sungai dan muara berkisar $5-20$ $\%$. Perbedaan salinitas air laut dengan air sungai yang bertemu di muara menyebabkan keduanya bercampur membentuk air payau. Karena kadar garam air laut lebih besar, maka air laut cenderung bergerak di dasar perairan sedangkan air tawar di bagian permukaan. Menurut Ghufran (2007), anakan udang jenis Penaeus menyesuaikan diri pada salinitas yang bervariasi antara $4-35 \%$. Udang penaeus memiliki toleran yang tinggi terhadap kadar garam. Udang ini mampu menyesuaikan diri terhadap salinitas $4-35 \%$.

Hasil perhitungan nested (hierarchical) analysis of variance bahwa stasiun Sungai dan Muara mempengaruhi perbedaan jumlah juvenil udang yang tertangkap, sedangkan titik yang terletak pada setiap stasiun tidak mempengaruhi. Jika dilihat dari hasil kelimpahan tangkapan, analisa ini membuktikan bahwa jumlah tangkapan antara sungai dan muara berbeda. Taraf kepercayaan yang digunakan adalah 95\%. Menurut Srigandono (1981), pada umumnya dilakukan uji dengan taraf kepercayaan 95\% yang berarti terdapat 5 kesalahan dari 100 uji atau 1/20 nya. Analisa nested dapat memberi kesimpulan yang berbeda pada grup dan subgrup. Menurut Zar (1984), menggunakan nested anova (juga dikenal sebagai hierarchical) ketika memiliki satu variabel pengukuran dan dua atau lebih variabel nominal. Variabel nominal bersarang, yang berarti bahwa setiap nilai dari satu variabel nominal (subgrup) ditemukan dalam kombinasi dengan hanya satu nilai dari tingkat yang lebih tinggi nominal variabel (grup).

\section{b. Hubungan Panjang Berat}

Berdasarkan penelitian yang dilakukan untuk mengetahui jumlah juvenil yang tertangkap dengan alat perangkap, dilakukan pula suatu pengukuran panjang total tubuh juvenil. Pengukuran ini untuk mengetahui tumbuh kembang darijuvenil tersebut dan mengetahui rata-rata ukuran panjang tubuh. Hubungan panjang dan berat udang merupakan salah satu parameter yang dapat digunakan untuk menganalisispola pertumbuhan suatu kelompok udang yang berguna dalam kegiatan pengelolaan perikanan.

Juvenil udang Metapenaeusmemiliki kisaran ukuran panjang sekitar 25 - $57 \mathrm{~mm}$ dan kisaran berat sekitar 0,18 - 1,17 gram. Juvenil udang Penaeus memiliki kisaran ukuran panjang sekitar 2,5 - 5,5 cm dan kisaran berat sekitar 0,18 - 1,15 gram. Menurut Sterrer (1986), juvenil udang merupakan tahapan menuju dewasa dengan bentuk hampir menyerupai induknya tetapi masih memiliki perbedaan pada ukuran tubuh. Kisaran ukuran panjang total pada jenis juvenil udang Penaeus memiliki kisaran panjang total $2-8 \mathrm{~cm}$. Pada tahapan juvenil, udang mulai menyukai berada di dasar perairan yang memiliki substrat lunak seperti lumpur atau pasir.

Nilai b yang didapatkan dari juvenil udang Metapenaeus adalah 2,414 dan nilai b juvenil udang Penaeus adalah 2,339. Nilai b yang didapat dari kedua udang tidak sama dengan 3. Hasil dari uji t nilainya signifikan 0 sehingga H0 ditolak H1 diterima. Nilai b pada kedua udang lebih kecil dari 3 yang berarti diperoleh kesimpulan bahwa sifat pertumbuhan allometrik negatif, artinya pertumbuhan panjang lebih cepat daripada pertumbuhan berat. Udang bertambah panjang pada tahap nauplius-mysis yang disebabkan oleh proses molting. Pada tahap memasuki juvenil, udang mulai kehilangan berat akibat berkurangnya masa air dalam tubuh udang. Menurut Saputra (2009), nilai b yang lebih besar atau lebih kecil dari 3 berarti pertumbuhan udang tersebut dapat dikatakan allometrik, nilai $\mathrm{b}<3$ maka pertumbuhan udang tidak seimbang dengan pertumbuhan beratnya. Pertambahan panjangnya lebih cepat daripada pertumbuhan beratnya. Hal ini diperkuat oleh Murni (2004), semakin tua umur udang maka pertambahan berat lebih besar dibandingkan pertambahan panjangnya, sedangkan pada udang muda (juvenil) pertambahan panjang lebih besar daripada pertambahan berat. Hal tersebut berarti bahwa pada umur tertentu, pertambahan berat akan lebih cepat dari pertambahan panjangnya dan saat mencapai tingkat kedewasaan tertentu, akan mencapai titik dimana udang tidak mengalami perubahan panjang.

\section{KESIMPULAN}

Kesimpulan yang diperoleh pada penelitian mengenai Hasil Tangkapan Juvenil Udang di Perairan Sungai dan Muara, Demak sebagai berikut :

1. Jenis juvenil udang yang tertangkap adalah genus Metapenaeus dan genus Penaeus;

2. Juvenil udang yang tertangkap dipengaruhi oleh dua stasiun berbeda (Sungai dan Muara);

3. Pola pertumbuhan juvenil udang Metapenaeus dan Penaeus adalah allometrik negatif.

\section{UCAPAN TERIMAKASIH}

Terimakasih penulis ucapkan kepada Prof. Dr. Ir. Sahala Hutabarat, M.Sc, Dr. Ir. Max Rudolf Muskananfola, M.Scdan Dr. Ir. Pujiono W. Purnomo, MSserta Churun Ain, S.Pi, M.Si yang telah memberikan arahan, bimbingan, serta kritik dan saran dalam penyusunan jurnal ini, serta semua pihak yang telah membantu dan memberikan dukungan. 


\section{DAFTAR PUSTAKA}

Arshad, A.S. M.N. Amin and N. Osman. 2010. Population Parameters of Planktonic Shrimp, Lucifer intermedius(Decapoda: Sargastidae) from Sungai Pulai Seagrass Area Johor, Peninsular Malaysia. Sains Malaysiana, 39(6): 877-882.

Effendie, M.I. 2002. Metode Biologi Perikanan. Yayasan Pustaka Nusantama.

Ghufran, M. 2007. Pengelolaan Kualitas Air dalam Budidaya Perairan. Penerbit Rineka Cipta. Jakarta.

Holthuis, L.B. 1980. FAO Species Catalogue: Vol. 1 - Shrimps and Prawns Of The World. FAO Fisheries Synopsis., 1(125).

Macia, A. 2004. Juvenile Penaeid Shrimp Density, Spatial Distribution and Size Composition in Four Adjacent Habitats within a Mangrove-Fringed Bay on Inhaca Island, Mozambique. Western Indian Ocean J., 3(2) : $163-178$.

Mudjiman, A. 1994. Budidaya Udang Putih. Penerbit Penebar Swadaya, Jakarta.

Murni, I. 2004. Kajian Tingkat Kematangan Gonad Udang Galah di Muara Sungai Kapuas Pontianak, Kalimantan Barat. Sekolah Pascasarjana. Institut Pertanian Bogor. Bogor.

Pratiwi, R. 2008. Aspek Biologi Udang Ekonomis Penting. Jurnal Oseana., 33(2) 15 - 24.

Raymond, T.B. 2011. Amphidromy and Migrations of Freshwatr Shrimps, Delivery of Hatching Larvae to the Sea, Return Juvenile Upstream Migration, and Human Impacts.Journal of Crustacean Biology, 28(4): $622-632$.

Riyana, H. 2015. Kelimpahan Larva Udang Penaeid Pada Saat Pasang di Saluran Tambak Desa Gempolsewu, Kab. Kendal. Diponegoro Journal of Maquares., 4(3) : 49 - 57.

Saputra, S.W. 2008. Pedoman Identifikasi Udang Subordo Macrura Natantia. Penerbit Universitas Diponegoro. Semarang.

Saputra, S.W. 2009. Dinamika Populasi Ikan. Universitas Diponegoro.

Saputra, S.W. 2015. Analisis Stok Udang Penaeid di Perairan Pantai Selatan Kebumen Jawa Tengah. Technical Report. PS. Manajemen Sumberdaya Perairan FPIK UNDIP.

Soekotjo. 2002. Analisis Distribusi dan Kelimpahan Udang Putih (Penaeus merguiensis de Man) di Perairan Teluk Semarang Sebagai Landasan Pengelolaan. Program Pascasarjana Universitas Diponegoro. Semarang.

Srigandono, B. 1981. Rancangan Percobaan (Experimental Designs). Penerbit Universitas Diponegoro. Semarang.

Sterrer, W. 1986. Marine Fauna and Flora of Bermuda. Awiley-Interscience Publication. John Wiley \& Sons Inc. New York.

Tjahjo, D.W. dan Suryandari Astri. 2013. Sebaran Horizontal Juvenil Udang di Perairan Laguna Segara Anakan. Jurnal Lit. Perikanan., 19 (3) : 131 - 137.

Zar, J. 1984. Biostatistical Analysis Second Edition. Prentice Hall, Inc. Englewood Cliffs. 